\title{
Analisis Situasi Pembangunan Manusia di Jawa Tengah
}

\author{
Laeli Sugiyono $^{1}$ \\ ${ }^{1}$ Badan Pusat Statistik Provinsi Jawa Tengah \\ ${ }^{1}$ laeli@bps.go.id
}

\begin{abstract}
This study aims to analyze the disclosure distribution of the position regency/city in Central Java based on the linkage of Economic Growth (EG) and Human Development Index (HDI). The study uses secondary data in the form of cross-sectional regional regency/city based on EG and HDI components. Data analysis uses regency/city distribution plot diagram based on EG and HDI components in the Cartesian diagram which divides the space into 4 Quadrants, namely: Quadrant I of the regency/city distribution plots with high EG and HDI, Quadrant II of the regency/city distribution plots with low EG and high HDI, Quadrant III of the regency/city distribution plots with high EG and low HDI, and Quadrant IV of the regency/city distribution plots with low EG and HDI. This study concludes that the position of cities in Central Java in general is in line with the Quadrant I group, the HDI of regency/city in the area of the ex-Semarang and exSurakarta residency is in Quadrant I. Other regencies/cities are spread in Quadrant II, III, and IV.
\end{abstract}

Keywords : human development index, economic growth, Central Java, distribution plot

\section{Latar Belakang}

Visi Provinsi Jawa Tengah (Jateng) adalah “Jawa Tengah berdikari dan semakin sejahtera”. Untuk mewujudkannya didasarkan pada tiga modal bangsa meliputi modal manusia, modal alam dan fisik serta modal sosial. Modal manusia memfokuskan untuk mewujudkan kehidupan masyarakat yang berkualitas dan bebas kemiskinan. Modal alam dan fisik dengan memanfaatkan kekayaan alam secara optimal dan berkelanjutan. Terakhir, modal sosial dengan mewujudkan sinergi kelompok birokrasi wirausaha dan pekerja menuju daya saing global.

Makna filosofis yang terkandung dalam visi Provinsi Jawa Tengah diartikan sebagai suatu daerah otonom yang mandiri dan maju. Daerah otonom selanjutnya disebut daerah adalah kesatuan masyarakat hukum yang mempunyai batas-batas wilayah yang berwenang mengatur dan mengurus urusan pemerintahan dan kepentingan masyarakat menurut prakarsa sendiri berdasarkan aspirasi masyarakat dalam sistem Negara Kesatuan Republik Indonesia (NKRI). Daerah menunjukkan suatu kesatuan pemerintahan dan kemasyarakatan beserta semua potensi yang dimiliki.

Mandiri artinya pembangunan daerah sebagai usaha untuk mengisi kemerdekaan merupakan upaya membangun kemandirian. Kemandirian bukan berarti situasi dan 
kondisi dalam keterisolasian. Maju artinya pelaksanaan pembangunan daerah senantiasa dilandasi dengan keinginan bersama untuk mewujudkan masa depan yang lebih baik secara fisik maupun nonfisik didukung oleh sumber daya manusia yang unggul dan berdaya saing tinggi, berperadaban tinggi, profesional serta berwawasan ke depan yang luas. Maju juga diarahkan pada terbentuknya sumber daya manusia yang memiliki daya dari sisi ekonomi, pendidikan, serta berdaya dari diri sendiri. Guna mencapai sumber daya manusia yang unggul, berdaya saing tinggi, berperadaban tinggi professional, dan berwawasan kedepan yang luas maka diperlukan suatu perencanaan yang terarah dan terukur tehadap pembangunan manusia.

Di era modern saat ini pembangunan manusia (human development) telah mengalami pergeseran makna. Jika dua-tiga dekade yang lalu, pembangunan manusia diukur hanya berdasarkan mata pencaharian yang dimiliki individu sebagai simbol kekayaan dan kesejahteraan ekonomi, maka dewasa ini konsep tersebut telah berkembang seiring perkembangan waktu.

United Nations Development Programme (UNDP) mendeskripsikan bahwa dimensi pembangunan terdiri atas dua aspek yaitu aspek pertama peningkatan kemampuan manusia, yang terdiri peningkatan waktu hidup yang lebih lama dan sehat, peningkatan pengetahuan, serta peningkatan standar hidup yang layak dan aspek kedua penciptaan kondisi yang memungkinkan terjadinya pembangunan manusia. Beberapa elemen yang terkait dengan hal tersebut adalah partisipasi dalam politik dan komunitas, kondisi lingkungan dalam jangka panjang, hak dan rasa aman bagi setiap individu, serta terciptanya kesetaraan dan keadilan sosial [1].

Pembangunan manusia merupakan salah satu faktor penting dalam pertumbuhan ekonomi [2]. Sumber daya manusia yang berkualitas memiliki produktifitas tinggi sehingga mampu meningkatkan efisiensi kegiatan ekonomi dan secara agregat dapat memengaruhi pertumbuhan ekonomi [3]. Ranis dan Steward [4] menyatakan bahwa pembangunan manusia merupakan kontributor dari stabilnya proses pertumbuhan ekonomi dan tidak hanya berkontribusi terhadap tujuan fundamental pembangunan, tetapi juga sebagai faktor penting terhadap pertumbuhan ekonomi sepanjang waktu.

Berdasarkan uraian permasalahan dalam latar belakang tersebut, maka kontribusi dari penelitian analisis situasi pembangunan manusia di Jawa Tengah diharapkan dapat 
memberikan pemahaman ilmu pengetahuan pembangunan manusia dengan fokus wilayah Jawa Tengah, yang praktis dan komprehensif dan didukung data empirik.

Penelitian analisis situasi pembangunan manusia di Jawa Tengah dimaksudkan untuk memberikan gambaran pencapaian pembangunan manusia sesuai visi misi dan rencana pembangunan jangka menengah dan jangka panjang kepada Pemerintah Provinsi Jawa Tengah khususnya, dan masyarakat luas pada umumnya.

\section{Tinjauan Pustaka}

2.1. Gagasan Pembangunan Manusia. Perspektif pembangunan manusia merupakan sebuah pemikiran radikal dalam konsep pembangunan. Perspektif ini menggantikan konsep pertumbuhan ekonomi dan pertumbuhan pendapatan per kapita yang digunakan oleh perencana kebijakan sebelumnya. Pertumbuhan ekonomi yang dipandang dari sisi perdagangan, investasi, dan teknologi merupakan hal yang esensial. Akan tetapi, hal itu hanya melihat manusia sebagai alat untuk mencapai pertumbuhan, dan bukan sebagai tujuan dari pembangunan. Pembangunan manusia memperluas pembahasan tentang konsep pembangunan dari diskursus tentang cara-cara dalam pertumbuhan Produk Domestik Bruto (PDB) ke diskursus tentang tujuan akhir dari pembangunan. Pembangunan manusia juga merupakan perwujudan jangka panjang, yang meletakkan pembangunan di sekeliling manusia, dan bukan sebaliknya manusia di sekeliling pembangunan [5].

Mengutip UNDP [1], pembangunan manusia adalah suatu proses untuk memperbanyak pilihan-pilihan yang dimiliki oleh manusia. Diantara banyak pilihan tersebut, pilihan yang terpenting adalah untuk berumur panjang dan sehat, untuk berilmu pengetahuan, dan untuk mempunyai akses terhadap sumber daya yang dibutuhkan agar dapat hidup secara layak.

2.2. Definisi Pembangunan Manusia. Teori pembangunan manusia didefinisikan sebagai proses perluasan pilihan masyarakat. Pada prinsipnya, pilihan manusia sangat banyak jumlahnya dan berubah setiap saat. Tetapi pada semua level pembangunan, ada tiga pilihan yang paling mendasar yaitu untuk berumur panjang dan hidup sehat, untuk memperoleh pendidikan dan untuk memiliki akses terhadap sumber-sumber kubutuhan agar hidup secara layak. Apabila ketiga hal mendasar tersebut tidak dimiliki, maka pilihan lain tidak dapat diakses [5]. 
Pembangunan manusia memiliki dua sisi. Pertama, pembentukan kapabilitas manusia seperti peningkatan kesehatan, pendidikan, dan kemampuan. Kedua, penggunaan kapabilitas yang mereka miliki, seperti untuk menikmati waktu luang, untuk tujuan produktif atau aktif dalam kegiatan budaya, sosial, dan urusan politik. Apabila skala pembangunan manusia tidak seimbang, kemungkinan akan terjadi ketidakstabilan. Berdasarkan konsep pembangunan manusia, pendapatan merupakan salah satu pilihan yang harus dimiliki. Akan tetapi, pembangunan bukan sekadar perluasan pendapatan dan kesejahteraan. Pembangunan manusia harus memfokuskan pada manusia.

2.3. Pengukuran Pembangunan Manusia. Menurut UNDP, Indeks Pembangunan Manusia (IPM) mengukur capaian pembangunan manusia berbasis sejumlah komponen dasar kualitas hidup. Sebagai ukuran kualitas hidup, IPM dibangun melalui pendekatan tiga dimensi dasar. Dimensi tersebut mencakup:

a. Umur panjang dan hidup sehat (a long and healthy life) yang diukur dengan indikator Umur Harapan Hidup saat lahir (UHH);

b. Pengetahuan (knowledge) yang diukur dengan indikator Harapan Lama Sekolah (HLS) dan indikator Rata-rata Lama Sekolah (RLS); dan

c. Standar hidup layak (decent standard of living); yang diukur dengan indikator Produk Domestik Bruto (PDB) per kapita.

2.4. Metode Perhitungan IPM. IPM pertama kali diperkenalkan oleh UNDP pada tahun 1990, mencakup tiga komponen yang dianggap mendasar bagi manusia dan secara operasional mudah dihitung untuk menghasilkan suatu ukuran yang merefleksikan upaya pembangunan manusia. Untuk penghitungan tahun 2019 merujuk metode baru IPM 2014 [5], penghitungan diperbaharui dari rata-rata aritmatik menjadi rata-rata geometrik dirumuskan seperti persamaan (1):

$$
I P M=\sqrt[3]{X_{1} X_{2} X_{3} .100 \%}
$$

$X_{1} \quad$ : Indeks harapan hidup saat lahir.

$X_{2} \quad$ : Indeks pendidikan $=1 / 2 \times$ (indeks harapan lama sekolah dan rata-rata lama sekolah).

$X_{3} \quad$ : Indeks standar hidup layak (indeks pdb per kapita) didekati dengan indeks pengeluaran perkapita yang disesuaikan.

Proses perolehan indeks $X_{I} ;(i=1,2,3)$ adalah dengan membandingkan antara selisih nilai suatu indikator dan nilai minimumnya dengan selisih nilai maksimum dan nilai minimum indikator yang bersangkutan, dapat dirumuskan dengan persamaan (2): 
Indeks $X_{(i, j)}=\frac{X_{(i, j)}-X_{(i-\min )}}{X_{(i-m a k s)}-X_{(i-\min )}}$

dengan

$X_{(i, j)}$ : indikator ke- $i$ daerah ke-j; $(i=1,2,3)$

$X_{(i)}$ maks : nilai maksimum dari $X_{(i)}$

$X_{(i)} \min :$ nilai minimum dari $X_{(i)}$

Nilai maksimum dan nilai minimum indikator $X_{(i)}$ [5] disajikan pada Tabel 1.

Tabel 1. Nilai Maksimum dan Minimum Komponen IPM

\begin{tabular}{clccc}
\hline No & \multicolumn{1}{c}{ Komponen IPM } & $\begin{array}{c}\text { Nilai } \\
\text { Maksimum }\end{array}$ & $\begin{array}{c}\text { Nilai } \\
\text { Minimum }\end{array}$ & Keterangan \\
\hline 1 & Umur Harapan Hidup Saat Lahir & 85 & 20 & Standar UNDP \\
2 & Harapan Lama Sekolah & 18 & 0 & Standar UNDP \\
3 & Rata-rata Lama Sekolah & 15 & 0 & $\begin{array}{c}\text { Standar UNDP } \\
\text { Standar UNDP } \\
\text { menggunakan } \\
\text { PNB riil per } \\
\text { kapita yang telah } \\
\text { disesuaikan }\end{array}$ \\
\hline
\end{tabular}

keterangan:

*) Daya beli maksimum merupakan nilai tertinggi kabupaten yang diproyeksikan hingga tahun 2025 (akhir RPJPN) yaitu perkiraan pengeluaran per kapita Jakarta Selatan tahun 2025.

**) Daya beli minimum merupakan garis kemiskinan terendah kabupaten tahun 2010 (data empiris) yaitu di Tolikara-Papua. pembangunan manusia didefinisikan sebagai proses perluasan pilihan masyarakat.

UHH didefinisikan sebagai rata-rata perkiraan banyak tahun yang dapat ditempuh oleh seseorang sejak lahir [5]. UHH mencerminkan derajat kesehatan suatu masyarakat. UHH dihitung dari hasil sensus dan survei kependudukan. HLS didefinisikan lamanya sekolah (dalam tahun) yang diharapkan akan dirasakan oleh anak pada umur tertentu di masa mendatang [5]. Diasumsikan bahwa peluang anak tersebut akan tetap bersekolah pada umur-umur berikutnya sama dengan peluang penduduk yang bersekolah per jumlah penduduk untuk umur yang sama saat ini. HLS dihitung untuk penduduk berusia 7 tahun ke atas. HLS dapat digunakan untuk mengetahui kondisi pembangunan sistem pendidikan di berbagai jenjang yang ditunjukkan dalam bentuk lamanya pendidikan (dalam tahun) yang diharapkan dapat dicapai oleh setiap anak. 
RLS didefinisikan sebagai jumlah tahun yang digunakan oleh penduduk dalam menjalani pendidikan formal [5]. Diasumsikan bahwa dalam kondisi normal rata-rata lama sekolah suatu wilayah tidak akan turun. Cakupan penduduk yang dihitung dalam penghitungan rata-rata lama sekolah adalah penduduk berusia 25 tahun ke atas.

Indeks Pengeluaran per kapita yang disesuaikan ditentukan dari nilai rata-rata pengeluaran per kapita dan paritas daya beli (purchasing power parity (PPP)). Rata-rata pengeluaran per kapita dan PPP setahun diperoleh dari Susenas, dihitung dari level provinsi hingga level kabupaten/kota. Rata-rata pengeluaran per kapita dan PPP dibuat konstan atau riil dengan tahun dasar 2012=100. Perhitungan PPP pada metode baru menggunakan 96 komoditas dimana 66 komoditas merupakan makanan dan sisanya merupakan komoditas non makanan. Metode penghitungan PPP menggunakan metode Rao [5].

$P P P_{j}=\prod_{i=1}^{m}\left(\frac{p_{i j}}{p_{i k}}\right)^{1 / m}$

dengan

$p_{i j}$ : harga komoditas $i$ di kabupaten/kota $j$

$p_{i k}$ : harga komoditas $i$ di Jakarta Selatan

$m$ : jumlah komoditas.

2.5. Klasifikasi IPM. Untuk keperluan analisis situasi pembangunan manusia, capaian IPM suatu wilayah diklasifikasikan menurut kategori rendah, sedang, tinggi, dan sangat tinggi. Klasifikasi IPM wilayah secara rinci dapat dilihat pada Tabel 2.

Tabel 2. Klasifikasi Nilai IPM

\begin{tabular}{rcc}
\hline No & Kriteria & Klasifikasi IPM \\
\hline 1 & Rendah & $<60$ \\
2 & Sedang & $60 \leq$ IPM $<70$ \\
3 & Tinggi & $70 \leq$ IPM $<80$ \\
4 & Sangat Tinggi & IPM $\geq 80$ \\
\hline
\end{tabular}

2.6. Perhitungan Pertumbuhan. Penghitungan pertumbuhan dapat didekati secara linear dan eksponensial. Pertumbuhan linear digunakan untuk menyatakan perkembangan dari suatu perubahan dari tahun dasar ke tahun tertentu [6], yaitu:

$P_{t}=(1+r) P_{0}$

sehingga tingkat pertumbuhan atau perkembangan dihitung sebagai:

$r=\frac{P_{t}-P_{0}}{P_{0}} \times 100 \%$ 
Pertumbuhan yang menyatakan perkembangan secara rata-rata setiap tahun dari suatu perubahan dari tahun dasar ke tahun tertentu, mengikuti kaedah eksponensial yaitu:

$P_{t}=(1+r)^{n} P_{0}$

sehingga tingkat pertumbuhan atau perkembangan dihitung dengan

$r=\frac{L_{n} P_{t}-L_{n} P_{0}}{n} \times 100 \%$

dengan

$P_{0}:$ item pada tahun dasar

$P_{t}:$ item pada tahun tertentu $t$

$n$ : lamanya tahun perubahan

$r$ : tingkat pertumbuhan atau perkembangan.

2.7. Petumbuhan Ekonomi dan Pembangunan Manusia. Koneksi antara pertumbuhan ekonomi dan pembangunan manusia terbentuk dalam dua rantai yang menunjukkan hubungan yang signifikan di kedua arah, terutama terkait dengan pengeluaran publik untuk kesehatan dan pendidikan, tingkat investasi dan distribusi pendapatan yang signifikan [4]. Variabel Kesehatan dan pendidikan merupakan komponen pembentuk IPM [5].

Meningkatnya pertumbuhan ekonomi suatu wilayah dalam jangka panjang dapat mendorong meningkatnya pendapatan masyarakat di wilayah tersebut. Meningkatnya pendapatan masyarakat secara agregasi bisa memperluas akses terhadap pendidikan dan kesehatan yang berimplikasi terhadap meningkatnya kualitas pembangunan manusia.

Ranis dan Stewart [4] memberikan kesimpulan bahwa terdapat hubungan keterkaitan pertumbuhan ekonomi dan pembangunan manusia yang digambarkan oleh variabel rata-rata pertumbuhan perkapita lag dengan pengeluaran sosial yang ditetapkan melalui pengeluaran publik untuk kesehatan dan pendidikan.

\section{Metode Analisis}

3.1. Analisis Deskriptif. Analisis deskriptif memberikan gambaran situasi data menurut pengukuran tendensi pusat seperi rataan dan persentase, serta pengukuran dustribusi data yang disajikan dalam bentuk gambar grafik yang mudah dipahami.

3.2. Analisis Pertumbuhan Ekonomi. Pertumbuhan ekonomi merupakan proses kenaikan output perkapita dalam jangka panjang. Pertumbuham ekonomi sangat tergantung pada output perkapita, dimana dalam hal ini ada dua hal yang harus diperhatikan yaitu output total dan jumlah penduduknya [7]. Berdasarkan sudut pandang tersebut, penelitian ini menggunakan istilah pertumbuhan ekonomi yang 
akan dilihat dari sudut pandang Produk Domestik Regional Bruto (PDRB) atas dasar harga konstan. Pertumbuhan ekonomi dapat diketahui dengan membandingkan PDRB pada tahun tertentu $\operatorname{PDRB}_{(t)}$ dengan PDRB sebelumnya $\operatorname{PDRB}_{(t-1)}$.

Pertumbuhan linear digunakan untuk menyatakan perkembangan dari suatu perubahan dari PDRB tahun tertentu $\operatorname{PDRB}_{(t)}$ dari PDRB tahun sebelumnya $\operatorname{PDRB}_{(t-1) \text {, }}$ yaitu:

$P D R B_{(t)}=(1+r) P D R B_{(t-1)}$

Tingkat pertumbuhan atau perkembangan dihitung sebagai berikut:

$r=\frac{L_{n} P D R B_{(t)}-L_{n} P D R B_{(t-1)}}{n} \times 100 \%$

\subsection{Analisis keterkaitan Indeks Pembangunan Manusia dan Pertumbuhan}

Ekonomi. Untuk melihat pengelompokan kabupaten/kota berdasarkan Angka Indeks Pembangunan Manusia (IPM) dan Tingkat Pertumbuhan Ekonomi (PE) digunakan diagram Kartesius yang membedakan angka IPM kabupaten kota dalam 4 (empat) kelompok, yaitu Kuadran 1: Kelompok IPM kabupaten/kota tinggi dengan kategori tingkat PE Tinggi. Angka IPM atau PE tinggi jika angka IPM kabupaten/kota atau tingkat PE kabupaten/kota lebih tinggi dari angka IPM rataan provinsi atau tingkat PE rataan provinsi. Sebaliknya angka IPM atau tingkat PE rendah jika angka IPM kabupaten/kota atau tingkat PE kabupaten/kota lebih rendah dari angka IPM rataan provinsi atau tingkat PE rataan provinsi.

Sebagai ilustrasi pengelompokan kabupaten/kota berdasarkan angka IPM dan PE dapat dilihat pada Gambar 1.

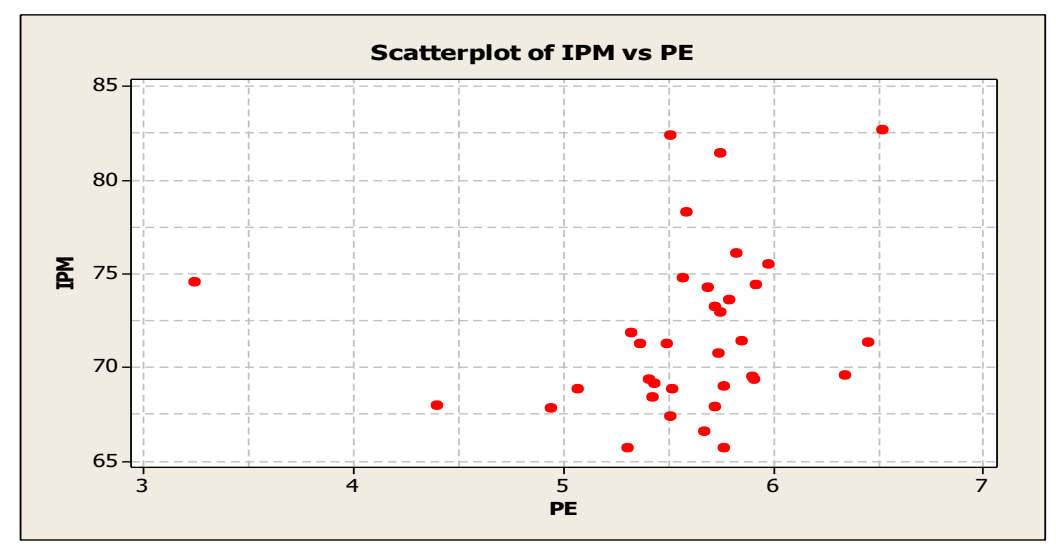

Gambar 1. Pengelompokan kabupaten/kota berdasarkan angka IPM dan PE 


\section{Hasil dan Pembahasan}

Sebaran kabupaten/kota menurut Angka Indeks Pembangunan Manusia (IPM) dan Tingkat Pertumbuhan Ekonomi (PE) sangat menarik untuk dikaji lebih mendalam seperti yang divisualisasi pada Gambar 1. Diagram kartesius menunjukkan sumbu garis vertikal adalah IPM dan sumbu garis mendatar adalah PE. Diagram tersebut membentuk empat ruang yang bisa dideskripsikan kedalam: 1). Kuadran I (IPM Tinggi dan PE Tinggi), Tinggi didefinisikan apabila angka IPM atau PE kabupaten/kota lebih tinggi dari IPM atau PE reratanya yang dicirikan oleh angka tingkat Provinsi Jawa Tengah; 2). Kuadran II (IPM Tinggi tetapi PE Rendah); 3). Kuadran III (IPM Rendah tetapi PE Tinggi); dan 4). Kuadran IV (IPM dan PE Rendah). Rendah didefinisikan apabila angka IPM atau PE kabupaten/kota lebih rendah dari IPM atau PE reratanya yang dicirikan oleh angka tingkat Provinsi Jawa Tengah.

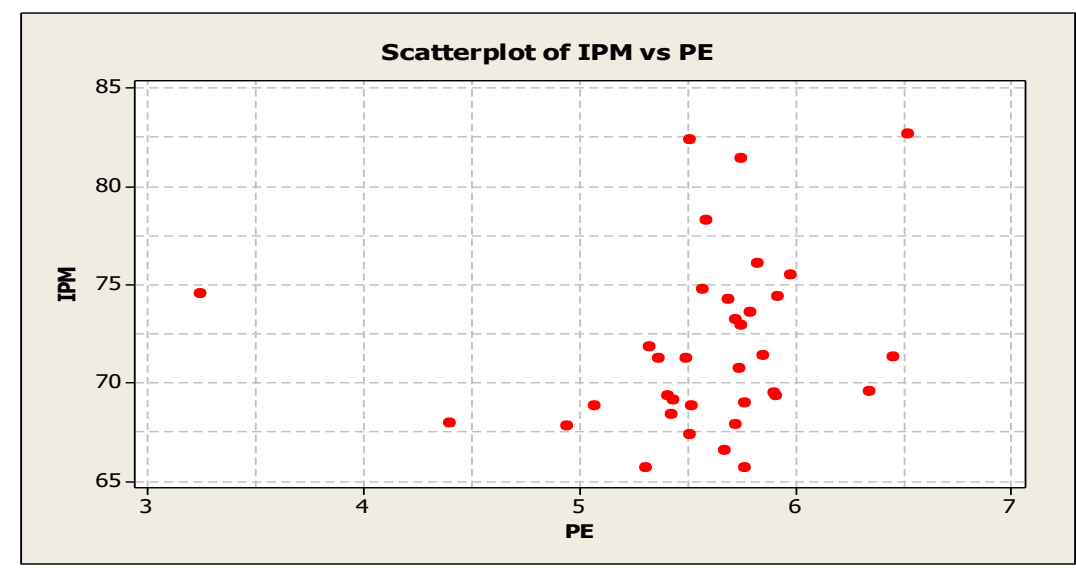

Gambar 2. Sebaran kabupaten/kota menurut angka IPM dan PE Provinsi Jawa Tengah Tahun 2018.

Hasil plot sebaran kabupaten/kota berdasarkan variabel Indeks Pembangunan Manusia dan variabel Pertumbuhan Ekonomi dikelompokkan menurut:

1. Kuadran I (IPM dan PE Tinggi), yaitu: (74) Kota Semarang, (73) Kota Salatiga, (72) Kota Surakarta (71), Kota Magelang, (75) Kota Pekalongan (76), (76) Kota Tegal, (02) Kabupaten Banyumas, (01) Kabupaten Cilacap.

2. Kuadran II (IPM Tinggi, PE Rendah), yaitu: (19) Kabupaten Kudus dan (06) Kabupaten Purworejo .

3. Kuadran III (IPM Rendah, PE Tinggi), yaitu: (27) Kabupaten Pemalang , (25) Kabupaten Batang, (04) Kabupaten Banjarnegara, (28) Kabupaten Tegal, (03) 
Kabupaten Purbalingga, (05) Kabupaten Kebumen, (26) Kabupaten Pekalongan, dan (17) Kabupaten Rembang.

4. Kuadran IV (IPM dan PE Rendah), yaitu: (16) Kabupaten Blora, (07) Kabupaten Wonosobo, (23) Kabupaten Temanggung dan (29) Kabupaten Brebes.

Kabupaten/kota di wilayah eks Kesidenan Semarang dan eks Keresidenan Surakarta berada di Kuadran I. Sedangkan Kabupaten Kota lainnya berada di Kuadran II, III, dan IV.

Posisi beberapa kota di Jawa Tengah secara umum sudah sesuai jalurnya berada pada kelompok Kuadran I (IPM dan PE Tinggi). Dua kabupaten yaitu Kabupaten Kudus dan Kabupaten Purworejo memiliki IPM Tinggi tetapi tidak didukung oleh PE yang Tinggi sehingga berada pada posisi Kuadran II (IPM Tinggi, PE Rendah).

Data pertumbuhan ekonomi Kabupaten Kudus dan Kabupaten Purworejo selama tahun 2010-2018, menunjukkan trend positif. Namun pertumbuhan ekonomi Kabupaten Kudus tahun 2018 Kabupaten Kudus tercatat rendah karena sub sektor industri kretek sedang mengalami perlambatan. Meskipun PE Kabupaten Kudus Rendah, akan tetapi kemampuan pemerintah Kabupaten Kudus yang konsisten dan fokus dalam pembangunan bidang kesehatan dan pendidikan telah memberikan bukti kuat dalam keberhasilannya membangun kualitas sumberdaya manusia yang tercermin oleh angka Indeks Pembangunan Manusia yang Tinggi.

Program Pendidikan yang diluncurkan pemerintah Kabupaten Kudus yang konsisten dalam mewujudkan Wajib Belajar 12 tahun yang terjangkau dan berkualitas dengan anggaran pendidikan tahun 2016 mencapai Rp.720,7 milyar atau sekitar 37\% dari APBD dan Program pemberian beasiswa bagi siswa yang kurang mampu dan pendampingan BOS mencapai Rp. 33,27 milyar yang menyebabkan tingkat partisipasi sekolah dalam jenjang SD hingga SLTA melalui Program Kelompok Belajar Paket A, B, dan $\mathrm{C}$ meningkat secara signifikan.

Selain gencarnya program pendidikan, pemerintah Kabupaten Kudus juga fokus dalam pembangunan pelayanan kesehatan melalui akreditasi standarisasi pelayanan kesehatan di tingkat puskesmas. Pelayanan kesehatan yang prima dan biaya murah mendorong meningkatnya kualitas kesehatan masyarakat. Hal ini terungkap dalam berita "Bupati Kudus Fokuskan Peningkatan Pelayanan Kesehatan" [8]. Dua program pendidikan dan kesehatan yang dilaksanakan secara konsisten di Kabupaten Kudus menjawab mengapa angka PE Rendah masih bisa mencapai IPM Tinggi. 
Kabupaten Purworejo yang kontribusi terbesarnya berasal dari Sektor Pertanian, Kehutanan dan Perikanan yang pada Tahun 2018 juga mengalami perlambatan sehingga berpengaruh pada agregasi PE tingkat kabupaten Rendah. Seperti halnya Kabupaten Kudus, Kabupaten Purworejo juga gencar membangun bidang pendidikan melalui Kejar Paket A, B, dan C yang diselenggarakan melalui Pusat Kegiatan Belajar Masyarakat (PKBM) yang tersebar di seluruh wilayah kecamatan di Kabupaten Purworejo.

Kabupaten Pemalang, Kabupaten Batang, dan Kabupaten Banjarnegara masuk dalam kelompok Kuadran III (IPM Rendah, PE Tinggi). Upaya peningkatan kualitas sumber daya manusia di Kabupaten Pemalang belum memberikan hasil yang menggemberikan yang tergambar oleh tingkat partisipasi sekolah dari tingkat dasar dan menengah yang masih stagnan rendah. Meskipun pertumbuhan ekonomi Kabupaten Pemalang tergolong Tinggi, akan tetapi akumulasi ekonomi yang ditimbulkannya belum serta merta diinvestasikan di sektor pendidikan.

Hal yang serupa juga terjadi di Kabupaten Batang dan Banjarnegara. Ini menjadi tantangan sekaligus pekerjaan rumah yang harus diselesaikan apabila tidak ingin pembangunan manusia tertinggal di wilayah Jawa Tengah. Meniru program nyata sektor pendidikan di Kabupaten Kudus dan Kabupaten Purworejo, seyogyanya Kabupaten Pemalang, Kabupaten Batang, dan Kabupaten Banjarnegara bisa lebih maju dan lebih baik dari Kabupaten Kudus dan Kabupaten Purworejo. Kabupaten Blora, Kabupaten Wonosobo, Kabupaten Temanggung, dan Kabupaten Brebes masuk dalam Kuadran IV (IPM dan PE Rendah).

\section{Kesimpulan dan Saran}

Berdasarkan hasil pembahasan diperoleh kesimpulan bahwa IPM Provinsi Jawa Tengah tahun 2018 tercatat sebesar 71.12 tergolong IPM tinggi. Kawasan regional Pulau Jawa IPM Provinsi Jawa Tengah berada pada peringkat keempat setelah Provinsi Jawa Barat sebelum Provinsi Jawa Timur. IPM Kabupaten Kota di wilayah eks Keresidenan Semarang dan eks Keresidenan Surakarta berada pada Kuadran I. Sedangkan kabupaten/kota lainnya berada pada Kuadran II, III, dan IV. Posisi beberapa kota di Jawa Tengah secara umum sudah sesuai jalurnya berada pada kelompok Kuadran I (IPM dan PE Tinggi). Dua kabupaten yaitu Kabupaten Kudus dan Kabupaten Purworejo memiliki IPM tinggi tetapi tidak didukung oleh PE yang tinggi sehingga berada pada posisi Kuadran II (IPM Tinggi, PE Rendah). Kabupaten Pemalang, Kabupaten Batang, dan Kabupaten Banjarnegara masuk dalam kelompok Kuadran III (IPM Rendah, PE Tinggi). 
Kabupaten Blora, Kabupaten Wonosobo, Kabupaten Temanggung, dan Kabupaten Brebes masuk dalam Kuadran IV (IPM dan PE Rendah).

Berdasarkan kesimpulan tersebut, maka disarankan Pemerintah kabupaten/kota di Jawa Tengah untuk fokus meningkatkan Pertumbuhan Ekonomi wilayah guna menstimulus meningkatnya Indeks Pembangunan Manusia. Disamping program meningkatkan Pertumbuhan Ekonomi, perlu didukung program nyata untuk meningkatkan komponen IPM, yaitu Sektor Pendidikan dan Sektor Kesehatan.

\section{Daftar Pustaka}

[1] UNDP. Human Development Report 2015. United Nation Development Programe. New York. 2015.

[2] Ezkirianto, R dan Alexandi, M. F. Analisis Keterkaitan antara Indeks Pembangunan Manusia dan PDRB per Kapita di Indonesia. Jurnal Ekonomi dan Kebijakan Pembangunan. Institut Pertanian Bogor (IPB). Vol 2 No 1. 2013.

[3] Tjiptoherijanto, P. Pengembangan Sumber Daya Wanita dalam Menghadapi Globalisasi. Populasi Jurnal Kependudukan dan Kebijakan Universitas Gajahmada. Universitas Gajah Mada (UGM). https://doi.org/10.22146/jp.11498. 1996.

[4] Ranis, G. dan Stewart, F. Economic Growth and Human Development. World Development. Vol. 28 No 2 paper page 197-219. Pergamon. Printed in Great Britain. 2000.

[5] Badan Pusat Statistik (BPS). Indeks Pembangunan Manusia Metode Baru. Badan Pusat Statistik. Jakarta. 2014.

[6] Asra, A. Analisis Multivariabel Suatu Pengantar. In Media. Bogor. 2017.

[7] Boediono. Teori Pertumbuhan Ekonomi Edisi Pertama. BPFE. Yogyakarta. 1999.

[8] Olies, M. Bupati Kudus Fokuskan Peningkatan Pelayanan Kesehatan. RMOLJATENG. Jawa Tengah. 2019. 